\title{
Gustavo Arce Fustero. De espaldas a Cristo. Una historia del anticlericalismo en Colombia, 1849-1948. Medellín:
}

Editorial Universidad de Antioquia, 2018, 290 pp.

\author{
William Elvis Plata Quezada
}

Gustavo Arce Fustero es un historiador y sociólogo español que tuvo una expe$\checkmark$ riencia de estudios en Colombia a comienzos de la década de 2000. Mientras cursaba su maestría en la Universidad Industrial de Santander inició una interesante investigación sobre los imaginarios clericales y anticlericales en España y Colombia, que continuó y amplió en su tesis doctoral de la cual se deriva el libro que reseñamos. ${ }^{1}$

Se trata de un texto sustentado en una amplia bibliografía, así como en documentación hallada en el Archivo Central del Cauca (Popayán) y en diversos periódicos especialmente de Bogotá, Popayán y Bucaramanga. Se sirve además de panfletos, opúsculos y hojas sueltas que reposan en bibliotecas que no se mencionan. A nivel teórico la obra se basa en clásicos de la sociología y de la antropología de la religión y de la cultura, como Max Weber, Émile Durkheim, Clifford Geertz, Claude Lévi-Strauss y Norbert Elias.

Arce presenta el anticlericalismo, objeto de su trabajo, como producto de la modernidad que generó una crisis de sentido entre la cosmovisión secularizada, que intentó apartar a la institución eclesiástica de la sociedad, y la intransigencia de la Iglesia a ceder su papel tradicional. El autor considera que en este contexto el liberalismo de los siglos XIX y XX procuró desacralizar la figura del cura para salvaguardar la esencia del cristianismo, supuestamente corrompido por dichos "emisarios" de Dios. El anticlericalismo conllevaba la desacralización o secularización de la figura del sacerdote católico, aquel comprometido en política, que, según el liberalismo, había abandonado su función espiritual por dedicarse a cuestiones mundanas.

* Profesor Asociado, Escuela de Historia, Universidad Industrial de Santander.

1. Gustavo Arce Fustero, "De santos y de diablos: una historia comparada del conflicto político social y simbólico entre clericales y anticlericales en España y Colombia (1930-1948)" (Tesis de maestría en Historia, Universidad Industrial de Santander, 2003); Gustavo Arce Fustero, "De espaldas a Cristo: una historia del conflicto anticlerical en la Colombia contemporánea (18491948)" (Tesis de doctorado en Historia, Universidad de Zaragoza, 2015). 
De acuerdo con el autor, el anticlericalismo colombiano inició a mediados del siglo XIX y se nutrió de las polémicas surgidas a propósito de las reformas liberales en materia eclesiástica (1850-1863). La "cosmovisión" liberal en su afán de procurar la "civilización" y el "progreso" del país vio como un obstáculo el poder e influencia social del clero católico, por lo cual orientó varias de las reformas a reducir dicho poder e influencia en lo político, educativo, económico y social. En este punto, Arce sitúa la intransigencia católica y la unión entre clero y conservadores como reacción defensiva a las reformas liberales.

La Regeneración y la guerra de los Mil Días fueron decisivas, según el autor, para la consolidación de una cosmovisión maniquea que dividió el escenario entre "buenos y malos", es decir, entre liberales y conservadores. El bipartidismo se fortaleció con la idea de pertenencia a un partido por la tradición, la cultura y la filiación de sangre; la sangre de los antepasados que murieron por sus ideales. Para el caso liberal, y en el desarrollo de la idea anticlerical, esta sangre derramada fue vista como una consecuencia de la legitimación de la violencia ejercida por el sacerdote, quien habría incitado a la violencia y a la guerra en los años precedentes.

Una de las tesis principales de la obra tiene que ver con lo que el autor llama una "iconoclastia" popular incitada. Según Arce, las élites liberales elaboraron una serie de imágenes anticlericales que incitaron a sectores del pueblo a atacar símbolos, templos, conventos y lugares sagrados durante los levantamientos armados. Estas imágenes eran las del "cura malo" que daba la espalda a su ministerio y profanaba su misión al actuar en política. Este cura perdía su condición sagrada; por tanto, debía rechazarse y aun atacarse. En contraposición, se encontraba la imagen del "cura bueno": aquel que solo se dedicaba a lo sagrado y no salía de las puertas del templo más que para ir a hacer obras de caridad o ejercer su ministerio. Este sacerdote sí guardaba su dignidad y debía ser respetado. De manera que atacar al "cura malo" y a sus símbolos podía llegar a ser un acto de purificación, de fe popular.

Las guerras civiles del siglo XIX habrían inculcado en la cultural popular la agresión y el sacrilegio de objetos sagrados. Arce registra acciones que van desde tomar licor en los cálices, mutilar imágenes sagradas, hasta tener relaciones sexuales en las iglesias. Esta acción popular tuvo dos momentos cúlmenes: la guerra de los Mil Días (1899-1902) y el Bogotazo (1948). La idea liberal de recuperar la esencia del cristianismo verdadero de las manos de los curas malos tomó forma en la fe popular e iconoclasta de un sector del pueblo, el cual asimiló al clero con el partido conservador y en consecuencia buscó la "purificación" del cristianismo a través de dichos actos.

Por su parte, la Regeneración procuró solidificar el proyecto de nación según una cosmovisión conservadora. Dicha cosmovisión reivindicaba el componente social y público del catolicismo a tal punto que ser católico se convertía en sinónimo de ser colombiano. Esto traía graves consecuencias, pues dejaba como apátridas a los protestantes, masones y, por supuesto, a los liberales que negaban su condición de católicos, pese a las protestas de varios de ellos, como Rafael Uribe Uribe. El autor presenta la satanización del otro como un elemento clave para 
reforzar el bipartidismo, como un instrumento privilegiado para consolidar cada grupo. Por ello, la "intransigencia con el error" expresada por el catolicismo y por el partido conservador se asumió como prueba de fortaleza de principios.

Este discurso del partido conservador sobre el liberal, si bien se amainó un poco tras la guerra de los Mil Días, reapareció con ímpetu durante la República Liberal (1930-1946). Una vez más, las reformas liberales fueron el detonante de la intransigencia conservadora: el matrimonio civil, la educación laica y la reforma constitucional, según Arce, se leyeron como parte de una persecución a la Iglesia, porque buscaban poner la fe cristiana en lo privado y no en la conciencia pública. Este esquema binario permeado por lo religioso fortaleció el bipartidismo: los liberales respondieron avivando sus antiguas concepciones y prácticas anticlericales, $\mathrm{y}$ todos fueron arrastrados hacia una nueva guerra religiosa donde cada grupo defendía el "verdadero cristianismo".

El autor puntualiza luego la relación entre religión, violencia y bipartidismo. Para Arce la violencia en Colombia fue sacralizada: tanto las ideas liberales como conservadoras se relacionaron con un halo atemporal y sagrado: la sangre de los antepasados suscribía la acción en una tradición y la intransigencia hacia el otro sacralizaba la acción partidista. En este contexto, el autor sitúa el paso de la violencia simbólica a la violencia real con el propósito de detallar las fronteras y depurar la identidad partidista y la cosmovisión de la realidad social. Así, cada partido respondió a la crisis de sentido generada por la modernidad, puesto que cada uno brindó una explicación coherente y lógica de la realidad en la que la vida y la muerte tenían propósito y coherencia.

Finalmente, el autor recrea la reacción destructiva del pueblo ante la muerte de Jorge Eliécer Gaitán el 9 de abril de 1948. Arce da poco peso a factores como el consumo de alcohol o a la posible influencia de figuras desestabilizadoras y, en cambio, considera que dicha destrucción se sitúa en una cultura anticlerical e iconoclasta arraigada en el pueblo que, si bien ya se había manifestado en la historia del país, nunca se había presentado de la manera como lo hizo aquellos días aciagos de abril de 1948. Es quizá el capítulo más débil y menos sustentado de todo el libro.

La obra concluye que el anticlericalismo en Colombia fue un vehículo crucial para la formación de identidades colectivas y políticas, y dotó de significación a muchas de las acciones y estrategias desacralizadoras y, por ende, secularizadoras del liberalismo. Asimismo, el anticlericalismo consolidó la sacralización de las fronteras políticas entre los conservadores y liberales.

Hagamos a continuación una valoración de esta obra. Ante todo, el análisis del anticlericalismo como elemento del conflicto político bipartidista es una valiosa aportación de Arce, quien desarrolló ideas ya expuestas previamente por José David Cortés y Fernán González, quienes señalaron la importancia que tuvo la cuestión religiosa en la formación de la identidad del partido conservador y liberal. ${ }^{2}$ Sin embargo, la contribución de Arce se encuentra en la presentación del

2. José David Cortés, Curas y políticos. Mentalidad religiosa e intransigencia en la diócesis de Tunja, 1881- 
anticlericalismo colombiano y la iconoclastia como un elemento cultural que, paradójicamente, se justificaba en lo sagrado.Así, el anticlericalismo jamás pretendió acabar la religión sino redefinirla y purificarla, debido a que para este la esencia del cristianismo se había corrompido cuando el clero le dio la espalda a Cristo al participar en política. La idea de la supuesta sacralización del anticlericalismo hizo que Arce leyera el Bogotazo desde otra lógica: se vio la destrucción como un acto de tabula rasa para empezar de nuevo.

Arce no logra explicar el proceso de asimilación y arraigo cultural del anticlericalismo en el pueblo. Es decir, la "fe popular" — como la llama el autorexpresada en la iconoclastia no fue bien articulada con el discurso anticlerical de la élite liberal. Ciertamente, las fuentes de las élites liberales expresan ideas que se refieren a la intención de buscar purificar el cristianismo ante una supuesta corrupción del clero. Sin embargo, Arce no explica el proceso de recepción y asimilación de dichas ideas entre los sectores populares. Al final queda la duda de por qué el pueblo consideraba que beber aguardiente en los cálices o tener relaciones sexuales en las iglesias significaba que se estaba purificando o recuperando la esencia del cristianismo. El autor presenta una somera explicación en lo que respecta a este punto. No obstante, una cosa es considerar al cura como politiquero, y por ende tratarlo como tal, y otra muy distinta la profanación de los recintos e imágenes sagradas. En consecuencia, anticlericalismo e iconoclastia no son sinónimos, ni consecuentes, como al parecer lo entiende Arce.

Esta falencia del texto se encuentra en el acercamiento metodológico. Desde el inicio Arce deja claro que el anticlericalismo no buscó reformas teológicas o doctrinales, sino la desacralización de la institución eclesiástica y su influencia en el campo social. Pero el simple hecho de considerar a la Iglesia como una institución sagrada que solamente debe enfocarse en el campo espiritual obedece a una concepción teológica en la cual la Iglesia pierde su papel de salvadora del mundo, algo que no puede aceptar dicha institución religiosa. Su teología la considera como mediadora de la presencia de Cristo en el mundo, como sacramento, es decir, medio de distribución de las gracias divinas. Esta concepción ayuda a comprender una de las razones principales del ardor con que el catolicismo ha abordado a lo largo de su historia la defensa de su presencia y acción en lo público. Arce, desde el momento en que ignora la comprensión teológica del anticlericalismo, divide el camino entre el anticlericalismo y la iconoclastia sin un punto de encuentro y explicación en el libro.

Por otra parte, en pos de probar una hipótesis delineada con antelación (el anticlericalismo como identidad liberal) el autor hace un uso un tanto descuidado de las fuentes, las cuales simplemente articula al hilo argumentativo, olvidando contextualizarlas. No hace, entonces, distinciones regionales (es claro que el liberalismo del centro del país no es igual en la costa Caribe, Santander o Cauca); 
ni diferencia muy bien las épocas: no es lo mismo el liberalismo o el conservatismo antes de 1863 que después de la guerra de los Mil Días. Tampoco tiene en cuenta la diversidad y las corrientes internas de la Iglesia católica. A pesar de su aparente homogeneidad, aún en el siglo XIX, el catolicismo se caracteriza por su diversidad interna, por la existencia de corrientes político-religiosas que iban desde la intransigencia hasta la conciliación con el liberalismo o con el socialismo. Esto no lo considera el autor. ¿No es posible pensar que, acaso, muchos de los anticlericales liberales no eran menos católicos que sus enemigos políticos conservadores? De hecho, al justificar las acciones anticlericales e iconoclastas como medios para una supuesta "purificación de la fe", podía pensarse que quizá había una actitud de fe sincera en los actores. Esto significa que la historia del Estado y de las luchas políticas en el país debería repensarse y mirarse desde otras lógicas distintas a las estructuras partidistas y dar mucha más importancia a las que están inmersas en intereses económicos, familiares y, por supuesto, en la fe y la religión, expresadas de muchas maneras. 